\title{
Influence of top management commitment towards the effective implementation of TQM in Iraqi oil companies
}

\author{
Abbas Abdulhameed Aletaiby ${ }^{1} \cdot$ Akila Pramodh Rathnasinghe $^{2}$ (D) $\cdot$ Pramodh Kulatunga $^{2}$
}

Received: 13 November 2020 / Accepted: 2 March 2021 / Published online: 14 March 2021

(c) The Author(s) 2021

\begin{abstract}
By raising performance, Total Quality Management (TQM) transforms any industry that is in a state of substantial structural change and facing increased competition. However, Iraq as one of the main global oil suppliers is still lagging on the TQM journey due to decreasing quality levels, particularly in management systems. Thus, this study aims to facilitate TQM in Iraqi Oil Companies by reviewing the TQM practices and the significance of Top Management Commitment (TMC) towards eliminating the barriers for implementation. To achieve this aim, the study utilises a mixed research approach and a single holistic case study strategy by triangulating literature and data collected from one of the leading Iraqi oil companies. The research identified TMC as the most influential factor for effective TQM implementation and six barriers. Furthermore, the research reveals the relationship between the top management commitment required for successful TQM implementation and barriers in that journey. This study will be the first of its kind in the Iraqi oil industry which will lead to a better understanding of TQM practices in Iraq and will encourage other researchers to extend this study through further work.
\end{abstract}

Keywords Total Quality Management (TQM) · Top Management Commitment (TMC) · Barriers for TQM · Iraqi Oil Companies

\section{Introduction}

Competing in the current global market conditions has compelled many organisations to adopt appropriate technological approaches, a skilled workforce and managers who possess the skills to coordinate all aspects of these modern trading conditions which places unprecedented emphasis on quality and customer satisfaction (Addis 2019; Castagena et al. 2020). This has led to the development of several approaches to quality management, the most prominent of which has been TQM.

According to Górny (2017), TQM is considered to be both a philosophy and methodology for managing companies, it provides the overall concept that fosters continuous improvement in a company. Thus, it is more than a

Akila Pramodh Rathnasinghe

akilar@uom.lk

1 Department of Business Administration, College of Administration and Economics, University of Basrah, Basra, Iraq

2 Department of Building Economics, University of Moratuwa, Moratuwa, Sri Lanka philosophy as it entails a methodological approach which draws on the strengths of statistical analysis as well as recognising the crucial role of employees at all levels to meet or exceed customer expectations (Besterfield et al. 2012). The type of industries and companies that adopt TQM to successfully meet their business objectives vary from small to large, public to private and from manufacturing to service (Ahmed and Lodhi 2015).

While the initial implementation of TQM started in Japan followed by the USA, European countries, and South-East Asian countries, in the developing countries in general and the Middle East, in particular, there has been a time lag in adopting TQM practices (Abd-Elwahed and El-Baz 2018). Jong, Sim and Lew (2019) illustrated that an unclear perception of quality management in developing countries is one of the TQM implementation gaps. In light of the Iraqi context, the oil industry is the main source of its income, as it is well known that the Iraqi economy relies on the export of oil and is dependent on the world's economy. However, the Iraqi economy is still underdeveloped in many aspects such as improved quality, product quality and operation methods compared with other developing and developed countries (Benghida 2017). Thus, the Iraqi oil companies

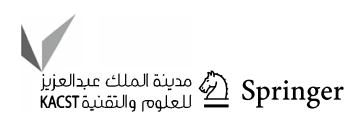


need to emphasise the significance of implementing TQM programmes, and its tools, practices and techniques. Moreover, there is also a lack of studies in terms of adopting and applying TQM in the Iraqi oil industry. Although various researchers including Ahmad and Elhuni (2014) and AlShammari (2013) tried to explore basic requirements and considerations for the implementation of TQM in the oil companies of adjoining countries to Iraq, there is no any complete guide to the management of these companies under TQM model. Further, it is important to highlight that those studies discussed TQM based on specific cultural, economic and social characteristics of any such region (Jones and Seraphim 2008). Hence, this study is expected to play an important role for the oil companies of Iraq to properly guide the companies about TQM and to support its implementation in this region. However, it should be noted that attempts to apply quality systems such as ISO9001 or QHSE have been undertaken recently in the Iraqi oil industry. Thus, through this study, the researcher seeks to investigate on the key factors and barriers that may hinder the successful implementation of TQM in the Iraq oil industry which would be an addition to the existing scholarly work on the quality assurance for the Iraq oil industry.

Accordingly, this paper is structured as follows. First, it provides a comprehensive literature review on the key factors and barriers for the TQM implementation. Next, the research method, comprising case study background, data collection and analysis techniques, is elaborated. This is followed by the findings and their discussion in light of releavant literature. Finally, the conclusions derived from the study are explained.

\section{Literature review}

This section aims at presenting a critical review of the literature relevant to an understanding and discussion of various concepts related to TQM. Also, the key factors of TQM implementation and the barriers that might hinder the success of TQM implementation are discussed in detail.

\section{Total quality management (TQM)}

TQM is a term that was initially coined by the Department of Defence in the USA (Sweis et al. 2019). TQM has developed through four stages of quality, namely inspection, quality control, quality assurance and TQM (Dale et al. 2013). Dahlgaard et al. (2007) saw inspection as an evaluation moment in the production process for quality assurance. Ismail (2012) viewed quality control through preventing and avoiding any shortcomings and observing operation processes to check whether they were functioning in such a way as to meet the required standards. The third stage of quality development emphasised organisational planning aimed at the eradication of defects and their occurrence. As the final stage, TQM was adopted in the 1980s as a means of improving quality so that US organisations could compete effectively with their Japanese counterparts (Madsen 2020). The TQM philosophy was seen as a response to Japanese competitiveness and was widely adopted because of its more refined techniques and its greater attention to all company stakeholders which included internal and external customers (Bouranta, Psomas, Suárez-Barraza \& Jaca, 2019). TQM was not confined to processes of production or delivery of service but also was applied to partnerships with suppliers and high-quality service to customers (Dale et al. 2013). By the 1990s, TQM offered organisations and service providers a new managerial approach to respond to the challenges presented by the often relentless market competition which prevailed (Pambreni et al. 2019). According to Siregar, Nasution and Sari (2017), many contemporary organisations adopted TQM due to its readiness to use innovative technology as a means of meeting the expectations of their customers. This involved a fundamental change from traditional management styles and a more in-depth appreciation of the role of the culture of the organisation in bringing about change. Thus, TQM came to be seen as indispensable for the long-term survival and sustainability of businesses as it involved the commitment of everyone at every level of the enterprise (García-Alcaraz et al. 2019). Therefore, TQM has the potential to transform industries that require restructuring to be able to effectively compete in market environments which have become highly competitive. In particular, the implementation of TQM in the Iraqi oil industry could result in the provision of an overall high-quality standard that contributes effectively to improving the entire performance.

\section{The key factors of TQM implementation}

To exploit the benefits provided by TQM, companies must manage the complex implementation process successfully. Thus, companies need to identify and evaluate the key factors when introducing TQM (Hietschold et al. 2014). The identification of key factors of TQM assists the companies to better understand the dynamic and active nature of TQM. TQM is about complex processes that focus on the company's culture, size, and management styles. Nevertheless, TQM has no general standard formula (Koh and Low 2010). Therefore, an extensive review of the literature was carried out to explore the concept and the main principles of TQM from leading writers on quality who have developed various approaches in the area of quality management. Table 1 shows the TQM factors that have been identified in this study as being significant to the successful TQM implementation and the literature support. 


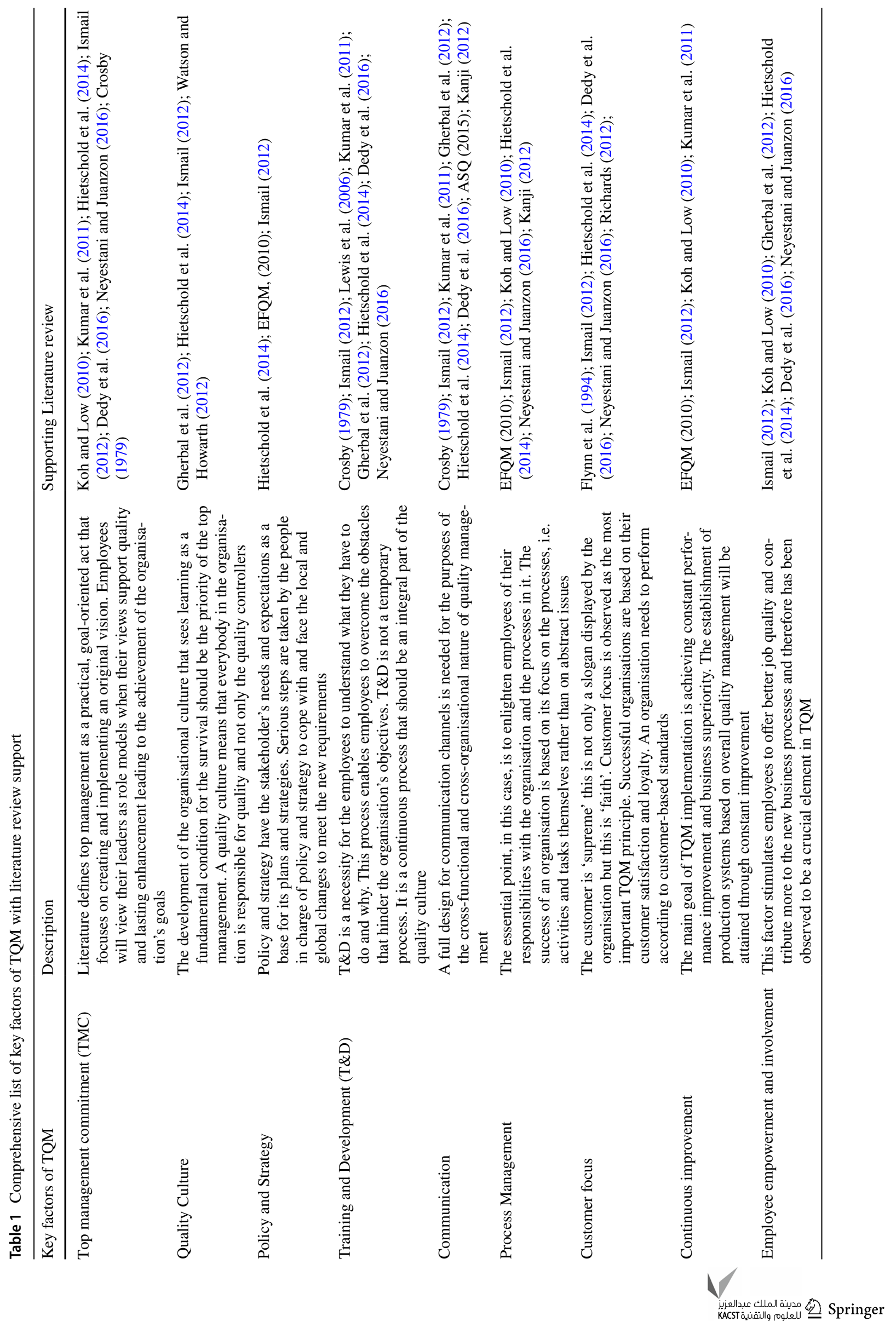




\section{Barriers to implementing TQM}

According to Jacobsen (2008), understanding the main factors that are likely to hinder the implementation of TQM urges the decision-makers to develop effective strategies for improving the opportunities of successful TQM implementation hence, moving towards excellence in the business. This research is primarily based in Iraq, which is considered to be one of the developing Arab countries and due to the lack of empirical efforts to study the barriers or obstacles that hinder the TQM implementation. Therefore, it is worthwhile to shed light on the barriers that impede TQM implementation in Arab countries where they have a similar business environment to that of Iraq. Consequently, this research mainly concentrated on the studies that acknowledged TQM barriers facing companies implementing TQM in Arab countries.

The existing TQM literature shows that many Arab companies in different industries encountered difficulties to reach the expected results of TQM. In Qatar, Al-Khalifa and Aspinwall (2000) conducted a study of 143 companies from the services, manufacturing and public sectors. The results of this study revealed that an authoritarian and hierarchical organisational structure, lack of managerial commitment, resistance from employees and managers, insufficient managerial competencies, inadequate infrastructure and non-supportive human resources management practices were the most important barriers affecting TQM implementation. Another empirical study was conducted in the Jordanian information and communications technology sector by Twaissi et al. (2008). The study revealed that the most significant barriers to TQM implementation in Jourdan were influences from the government policy, weaknesses of organisational culture, lack of continuous improvement and weakness of employee empowerment.

In Algeria, Berrouiguet (2013) identified four major barriers that impeded TQM implementation in Algerian manufacturing companies. These barriers were lack of top management support, a significant shortage of the knowledge and skills required to implement TQM, cultural change and inadequate financial resources. Alsughayir (2014) conducted a study to examine the barriers to implementing TQM in private medical services organisations in Saudi Arabia. The findings of the study revealed that the most significant barriers to TQM efforts included high employee turnover, which meant that the organisations focused more on employees' performance rather than improvements in quality. This is an indication that these organisations do not consider quality as an organisational objective. Also, a lack of understanding of the TQM philosophy is considered as a primary impediment to its successful implementation. In addition to the lack of motivation among employees would as well cause them to resist change due to a lack of understanding of the TQM concept and its importance.
Based on the aforementioned discussion, it is evident that the implementation of TQM is essential in many organisations because it provides it with a competitive advantage. However, most of the companies in developing countries in general and many Arab countries, in particular, are still in the initial stages of TQM and face difficulties and challenges towards implementing TQM effectively due to various barriers. In practice, it is essential to identify and address these barriers to facilitate achieving the high-performance management applications required for effective TQM implementation.

\section{Methodology}

This study inclined towards adopting an interpretivist philosophical stance rather than positivism. This is because of the need to gather perspectives regarding what quality means, key factors of TQM and barriers of adopting TQM from different people involved in Iraqi oil companies. Further, this study adopted the combination of deductive and inductive approaches where the combination of these approaches within the same research is often advantageous to address the main research aim of the study (Saunders et al. 2019). Abductive approach has been used to deduce the key elements of TQM from literature. The research also gathered a deeper understanding of the phenomenon of TQM from different perspectives depending on the perceptions of decision-makers and leaders in the company being investigated by choosing the inductive approach. Thus, the abductive approach led the order of data collection in this research (Żelechowska, Żyluk and Urbański 2020).

Due to the exploratory nature of this research, since there is little previous knowledge about the TQM implementation in the oil industry and no clear understanding of the oil companies in Iraq being researched, this research adopted case study data collection strategy as the most appropriate strategy for answering the research questions of this study. Accordingly, this research adopted a single holistic case study. According to Yin (2014), one of the main reasons for adopting a single case study is that it is considered as the representative, unique or typical company among many different companies in the same industry. Accordingly, a single case study data collection strategy was used as the most appropriate strategy because this research was focused on one of the most significant and unique oil companies in the Iraqi oil industry which is the Iraqi Drilling Company (IDC) with its three branches in south, center and north of Iraq (see Sub-Sect. 3.3). Yin (2014) stated that a single case study has allowed for two options, holistic design and embedded design. Because the IDC has the same administrative system in all its three branches, the research boundary takes the IDC as a case study boundary, hence a holistic design 
is appropriate. The unit of analysis of the research is TQM implementation within the IDC.

\section{Data collection techniques}

In this study, primary data were collected through questionnaires administered within the case study. The researcher targeted the questionnaire survey at specific managers and qualified employees in the company considering their significant involvement in quality assurance and strategic decision making relating to quality aspects of the oil production. Further, the questionnaire included different questions that are related to quality, quality management and TQM. These questions contain specific issues that were not relevant to all the employee force in the company. Therefore, the questionnaire survey has included only middle-level managers, junior-level managers and the staff of the quality management department in the company.

The questionnaire was consisted of questions asked about the key factors of TQM implementation and further asked about exploring barriers that hindered TQM implementation in the company. In terms of conducting a questionnaire out of the whole validated sample, nine questionnaires have been undertaken as a pilot experiment to evaluate possibility, time and adverse events.

To measure the relevant factors and indicators, the questionnaire invited responses by using a Likert scale. Many research design authors such as Saunders et al. (2019), Bishop and Herron (2015), and McLeod et al. (2011) commented on the usefulness of Likert scale for measuring the strength of agreement or disagreement with statements designed to gauge the relative importance of certain factors. However, in this research, a five-point scale was considered to be adequate for gauging strengths of opinion and that the middle neutral position is valid as it may genuinely reflect a respondent's position. The scale ranged from strongly disagree to strongly agree and was applied to statements used in the third and fourth sections of the questionnaire. The statements used within the Likert scale was first developed through the literature and refined and confirmed by five experts in the quality and TQM subject disciplines.

In this research, the population size for this study is consisted of a 249 number of participants including middle and junior managers as well as the staff of the quality management department of IDC Company. Therefore, to calculate the sample size, this study adopted the dictum laid by the Sekaran and Bogie (2010) where they calculated the sample size as 152 from a population of approximately 250 . Accordingly, a sample size of 152 for this study was obtained from survey Monkey: sample size calculator. Therefore, concerning the type of questionnaire survey sample, the researcher selected simple random sampling which allows the researcher to select a sample number without bias. It is best used when the researcher has an accurate sampling number that lists the entire population of the study.

\section{Data analysis}

Following Yin (2014), data analysis procedures can be defined as a process that contains examining, testing, classifying, tabulating or recombining quantitative evidence to address the preliminary proposition or findings of a study. Accordingly, descriptive and inferential statistics have been followed as the data analysis mechanisms in this study. The descriptive analysis of this study includes percentage tables and central tendency particularly, mean values. Besides, measures of variability and dispersion such as standard deviations were obtained. In determining the cell measurements for the Likert scoring the following procedure was followed: The range in the scores was from lowest score of 1 up to the maximum of 5 giving a range of $4(5-1=4)$. The number of cells was 5 so dividing the range by the number of cells gives a cell length of $0.8(5 / 4)$. Thus, the first cell length was $1+0.8=1.8$. This is illustrated in Table 2. A measure of dispersion is required to show the variation in the data and the standard deviation was used in this study as a most appropriate measure. Additionally, percentages were used for comparative purposes.

To achieve the purpose of this study, it was important to analyse the relationship between the main variables, by finding the relationship between the barriers that hindered TQM implementation and TMC as a key factor required for TQM implementation. In this study, the relationship between each of the two ranked variables classified as ordinally scaled, in addition to the normality test revealed that the data set are derived from non-normal distributions. Therefore, this study relied on the nonparametric test, with the ordinal type of data and Spearman correlation was utilised as an interferential statistical technique to be used. Furthermore, data analysis needed to present results obtained for each type of the variable, where the association between variables has been analysed. Thus, concerning the nature of this study, statistical measures of association and statistical trend detection methods have been employed. Accordingly, Excel and

Table 2 Likert Scale Interpretation (adopted from Nyutu et al. 2021)

\begin{tabular}{llll}
\hline Point Scale & Mean & $\begin{array}{l}\text { Qualitative interpreta- } \\
\text { tion }\end{array}$ & Level of agreement \\
\hline 1 & $1.00-1.80$ & Strongly disagree & Very low \\
2 & $1.81-2.60$ & Disagree & Low \\
3 & $2.61-3.40$ & Moderate & Moderate \\
4 & $3.41-4.20$ & Agree & High \\
5 & $4.21-5.00$ & Strongly agree & Very high \\
\hline
\end{tabular}


SPSS software programmes were mainly used for the data analysis procedures.

\section{Case study background}

As mentioned previously, the study was conducted in one of the leading oil companies in Iraq, the Iraqi Drilling Company. IDC was established in 1990 and is associated with the Ministry of Oil. The main goal of establishing IDC was to incorporate all activities related to the management and implementation of drilling, reclamation and the development of oil wells in several oil fields exclusively in one national company. The company's operations cover the entire Iraqi territory, through three main headquarters based in southern, central and northern Iraq.

The quality management or Quality Health, Safety and Environment (QHSE) department is deemed to be one of the important departments in IDC, especially as the company's policy is to complete its activities following the ISO international standards. In 2012, the company achieved a remarkable objective by acquiring an ISO9001: 2008, as the first Iraqi company in the oil sector to achieve this certificate. Even though IDC does not classify itself as a TQM company, its philosophy is derived from the adoption and implementation of the ISO9001: 2008 effectively. Moreover, despite their different objectives, both the TQM and ISO have some common elements, which is why many researchers such as Skrabec (1999), Sun (2000) and Escanciano et al. (2001) consider an ISO as the first step towards achieving TQM.

\section{Research findings}

This section presents the analysis of the data collected from the survey questionnaire. In this study, a total of 152 questionnaires were distributed to the eligible sample, of which 118 completed questionnaires were received as usable and ideal for the final analysis from participants, ranging from middle, junior and quality managers working in IDC. The research findings were expected to identify the most significant key factor and its relationship with barriers for successful TQM implementation in Iraqi Oil Companies. Descriptive and inferential statistics for the study have been produced by utilising SPSS (Statistical Package for Social Scientists 23). Accordingly, the key findings of the study were presented as descriptive and inferential data analysis.

\section{Descriptive data analysis}

In this study, the descriptive statistical analysis includes three sections. Section one deals with the familiarity with TQM factors and upon that the most significant key factor was decided. Section two focuses on the identified most significant key factor of TQM. Section three focuses on the barriers to implementing TQM in the company.

\section{Familiarity with TQM key factors}

This section deals with the familiarity of key factors required for TQM implementation in the company. Nine TQM factors were extracted from the literature review; these factors were tested in the questionnaire to identify to what extent the participants were familiar with them. A 5 point Likert scale was used to measure the responses which are presented in Table 3.

TMC, customer focus, continuous improvement and training and development, recorded over $90 \%$ (a combined percentage) of familiarity and strong familiarity among the participants. In the same context, the remainder of the factors recorded over $80 \%$ (a combined percentage) of familiarity and strong familiarity among the respondents.

The results have illustrated that not one of the participants was unfamiliar with TQM key factors. Also, the results have shown that the highest percentage of low familiarity was recorded for employee empowerment and participation at
Table 3 The level of familiarity with the following TQM key factors or principles in percentage (\%)

\begin{tabular}{lllccc}
\hline TQM Key factors & Not familiar & $\begin{array}{l}\text { Low } \\
\text { familiarity }\end{array}$ & Not sure & Familiarity & $\begin{array}{l}\text { Strong } \\
\text { familiar- } \\
\text { ity }\end{array}$ \\
\hline Top management commitment & 0 & 1.5 & 3.9 & 45.7 & 48.9 \\
Customer focus & 0 & 2.6 & 6.4 & 43.1 & 47.8 \\
Continuous improvement & 0 & 3.2 & 5.5 & 42.7 & 48.6 \\
Process management & 0 & 3.1 & 8.4 & 43.7 & 43.8 \\
Training and development & 0 & 3.2 & 6.4 & 45.9 & 44.5 \\
Quality culture & 0 & 6.7 & 12.4 & 41.3 & 39.6 \\
Policy and strategy & 0 & 8.1 & 11.2 & 38.9 & 41.8 \\
Employee empowerment & 0 & 8.6 & 9.5 & 41.3 & 40.6 \\
Communication & 0 & 4.2 & 12.3 & 43.1 & 40.4 \\
\hline
\end{tabular}


$8.6 \%$, while, the lowest percentage of low familiarity was $\mathrm{TMC}$ at $1.5 \%$. Overall, the main pattern visible from the participants is that the most popular response is of the "strong familiarity" category followed by "familiar" and "Not sure". On the other hand, a few respondents fell into the "low familiarity" category and none in the "not familiar" category. Therefore, based on the above results it was assumed that the participants have extensive familiarity and knowledge regarding the suggested key factors of TQM.

However, within the limitations of this study, it considered only the TMC factor as the most significant based on its highest familiarity and approval rate by the respondents. Accordingly, advance descriptive analysis was conducted considering the TMC factor on how it might affect to a successful TQM implementation.

\section{TMC as the most significant key factor for TQM implementation.}

The value of factor has been measured by a group of questions, that is built on five points of the Likert scale ( $1=$ strongly disagree, $2=$ disagree, $3=$ neither agree nor disagree, $4=$ agree and $5=$ strongly agree). Therefore, to achieve the objective of both the research and this section, the top management key factor associated with specific questions, to identify and assess the features. Moreover, to enhance the findings, the researcher followed a descriptive analysis by using a ranking that is based on the highest percentage values, along with the highest mean value. Furthermore, the level of respondents' agreement for each statement is compared with the values of Table 2 in Sect. 3.2.

The data show that both choices, "strongly agree" and "agree", for the statements below, ranged between slightly higher than $75 \%$ and $84.7 \%$ of the whole respondents to the survey. On the other hand, both the "disagree" and "strongly disagree" choices, had the lowest percentages with an average of $6.8 \%$ of the whole respondents. Whereas, the percentages of the "neutral" choice ranged from slightly higher than $9 \%$ for the first statement to slightly less than $17 \%$ for the third statement of the whole respondents to the survey. Also, the results from Table 4 below are related to "top management commitment" and can be explained based on the average level of the respondents' agreement as follows:

Statement 1: "Top management continually demonstrates its commitment to quality". The percentage of respondents, who rated this statement as "strongly agree" and "agree" is at $84.7 \%$ of the whole respondents to the survey. According to the Likert scale interpretation, the mean value ranges from between 3.4 and less than 4.2, making the level of agreement for this statement high.

Statement 2: "Top management is inclined to allocate adequate time and resources for quality management". While, the percentage of participants, who rated this statement as both "strongly agree" and "agree", is slightly less than $84 \%$ of the whole respondents to the survey. According to the Likert scale interpretation, the mean value ranges from between 3.4 and less than 4.2, making the level of agreement for this statement high.

Statement 3: "Top management uses performance indicators to ensure adequate performance". The percentage of participants, who rated this statement as "strongly agree" and "agree", is slightly higher than $75 \%$ of the whole respondents to the survey. According to the Likert scale interpretation, the mean value ranges from between 3.4 and less than 4.2, making the level of agreement for this statement high.

\section{Barriers to implementing TQM in the company}

This section seeks to explore and determine the barriers that could prevent the successful implementation of TQM in the company. Therefore, to achieve the objective of both the research and this section, seven possible barriers were highlighted and each one of them was associated with specific questions to identify and assess the features of that barrier. Additionally, to enhance the findings, the researcher followed a descriptive analysis by using a ranking that is based on the highest percentage values, along with the highest mean value for each potential TQM barrier. Moreover, the level of respondents' agreement for each statement is compared with the values of Table 2 in Sect. 3.2.

Table 4 Descriptive statistics for top management commitment

\begin{tabular}{|c|c|c|c|c|c|c|c|}
\hline Statements & Strongly Agree & Agree & Neutral & Disagree & $\begin{array}{l}\text { Strongly } \\
\text { Disagree }\end{array}$ & Mean & SD \\
\hline $\begin{array}{l}\text { Top management continually demonstrates its commitment to quality } \\
\text { [Sub-factor 1] }\end{array}$ & 30.5 & 54.2 & 9.1 & 3.6 & 2.5 & 4.1 & 0.8 \\
\hline $\begin{array}{l}\text { Top management is inclined to allocate adequate time and resources for } \\
\text { quality management. [Sub-factor 2] }\end{array}$ & 23.7 & 60.2 & 9.3 & 5.1 & 1.7 & 3.9 & 0.8 \\
\hline $\begin{array}{l}\text { Top management uses performance indicators to ensure adequate perfor- } \\
\text { mance. [Sub-factor 3] }\end{array}$ & 19.4 & 55.8 & 16.9 & 4.3 & 3.4 & 3.9 & 0.9 \\
\hline
\end{tabular}




\section{Poor understanding and insufficient knowledge of TQM.}

The data related to the statement of poor understanding and insufficient knowledge of TQM shows that choices of "strongly agree" and "agree" for the below statements ranged between slightly higher than $60 \%$ and approximately $73 \%$ of the whole respondents to the survey. On the other hand, both the "strongly disagree" and "disagree" choices had the lowest percentages, that ranged from slightly higher than $10 \%$ for the statement of "There are difficulties in learning and implementing TQM" to $20.2 \%$ for the statement of "Poor understanding of the purposes and the benefits of TQM". Whereas, the percentages of the "neutral" choice were relatively high with an average of $17.3 \%$ of the whole respondents to the survey. Besides, the results from Table 5 below are about the "poor understanding and insufficient knowledge" statement, which can be explained based on the average level of respondents' agreement as follows:

Statement 1: "Poor understanding of the purposes and the benefits of TQM". The percentage of respondents, who rated this statement as "strongly agree" and "agree" is slightly higher than $61 \%$ of the whole respondents to the survey. According to the Likert scale interpretation, the mean value ranges between 3.4 and less than 4.2, making the level of agreement for this statement high.

Statement 2: "There is unclear awareness of TQM in the company". The percentage of respondents, who rated this statement as "strongly agree" and "agree" is slightly less than $68 \%$ of the whole respondents to the survey. According to the Likert scale interpretation, the mean value ranges between 3.4 and less than 4.2, making the level of agreement for this statement high.
Statement 3: "There are difficulties in learning and implementing TQM". The percentage of respondents, who rated this statement as "strongly agree" and "agree" is $72.8 \%$ of the whole respondents to the survey. According to the Likert scale interpretation, the mean value ranges between 3.4 and less than 4.2, making the level of agreement for this statement high.

\section{Resistance to change}

With regards to the data related to the statements of resistance to change, the choices of "strongly agree" and "agree" for the statements below ranged from between $51.7 \%$ and $79.6 \%$ with an average of $68.3 \%$ of the whole respondents to the survey. On the other hand, both the "strongly disagree" and "disagree" choices, ranged between slightly less than $12 \%$ and slightly higher than $28 \%$. Whereas, the "neutral" choice had a low percentage with an average of $14 \%$ of the whole respondents to the survey. Also, the results from Table 6 below regarding "resistance to change" can be explained based on the average level of respondents' agreement as follows:

Statement 1: "Employees prefer to follow instructions rather than take initiatives and create proposals in their jobs". The percentage of respondents, who rated this statement as "strongly agree" and "agree" is $79.6 \%$ of the whole respondents to the survey. According to the Likert scale interpretation, the mean value ranges between 3.4 and less than 4.2, making the level of agreement for this statement high.

Statement 2: "It is difficult to change the existing attitude of middle and junior management". The mean value of the agreement with this statement is $3.7 \%$, with a lower than

Table 5 Descriptive statistics for poor understanding and insufficient knowledge of TQM

\begin{tabular}{|c|c|c|c|c|c|c|c|}
\hline Statements & Strongly Agree & Agree & Neutral & Disagree & $\begin{array}{l}\text { Strongly } \\
\text { Disagree }\end{array}$ & Mean & SD \\
\hline Poor understanding of the purposes and the benefits of TQM. [B1.1] & 23.8 & 37.3 & 18.6 & 17.7 & 2.5 & 3.6 & 0.9 \\
\hline There is unclear awareness of TQM in the company. [B1.2] & 22.1 & 45.8 & 16.5 & 11.8 & 3.6 & 3.7 & 0.7 \\
\hline There are difficulties in learning and implementing TQM. [B1.3] & 27.9 & 44.9 & 16.9 & 4.2 & 5.9 & 3.8 & 0.7 \\
\hline
\end{tabular}

Table 6 Descriptive statistics for resistance to change

\begin{tabular}{|c|c|c|c|c|c|c|c|}
\hline Statements & Strongly Agree & Agree & Neutral & Disagree & $\begin{array}{l}\text { Strongly } \\
\text { Disagree }\end{array}$ & Mean & $\mathrm{SD}$ \\
\hline $\begin{array}{l}\text { Employees prefer to follow instructions rather than take initiatives and cre- } \\
\text { ate proposals in their jobs. [B2.1] }\end{array}$ & 35.5 & 44.1 & 8.4 & 4.3 & 7.6 & 4.0 & 0.8 \\
\hline $\begin{array}{l}\text { It is difficult to change the existing attitude of middle and junior manage- } \\
\text { ment. [B2.2] }\end{array}$ & 21.1 & 52.5 & 13.5 & 6.7 & 5.9 & 3.7 & 0.6 \\
\hline $\begin{array}{l}\text { Most of the staff are resistant to being involved in training and development } \\
\text { programmes. [B2.3] }\end{array}$ & 18.6 & 33.1 & 20.3 & 15.2 & 12.7 & 3.2 & 0 \\
\hline
\end{tabular}


the previous standard deviation of $0.6 \%$. The percentage of respondents, who rated this statement as "strongly agree" and "agree" is $73.6 \%$ of the whole respondents to the survey. According to the Likert scale interpretation, the mean value ranges between 3.4 and less than 4.2, resulting in the level of agreement for this statement being high.

Statement 3: "Most of the staff are resistant to being involved in training and development programmes". The percentage of respondents, who rated this statement as "strongly agree" and "agree" is $51.7 \%$ of the whole respondents to the survey. According to the Likert scale interpretation, the mean value ranges between 2.6 and less than 3.4, making the level of agreement for this statement moderate.

\section{Lack of delegation of authority and responsibility}

The data related to this statement shows that the choices of "strongly agree" and "agree" ranged between $65.3 \%$ to slightly higher than $71 \%$ of the whole respondents to the survey. On the other hand, both the "strongly disagree" and "disagree" choices ranged between slightly higher than $16 \%$ and slightly higher than $21 \%$. Besides, the percentages of the "neutral" choice had a relatively high percentage with an average of $14 \%$ of the whole respondents to the survey. Moreover, the result from Table 7 refers to the "Delegation of authority and responsibility", which can be explained based on the average level of respondents' agreement as follows:

Statement 1: "Lack of delegated authority from the top management to other managerial levels". The percentage of respondents, who rated this statement as "Strongly agree" and "agree", is $65.3 \%$ of the whole respondents to the survey. According to the Likert scale interpretation, the mean value ranges between 3.4 and less than 4.2, as a result, the level of agreement for this statement is high.

Statement 2: "Work responsibilities are not delegated at the company". The percentage of respondents, who rated this statement as "strongly agree" and "agree" is slightly less than $67 \%$ of the whole respondents to the survey. According to the Likert scale interpretation, the mean value ranges between 3.4 and less than 4.2, making the level of agreement for this statement high.

Statement 3: "Managers at middle and junior levels follow instructions more than creating proposals in their jobs". The percentage of respondents, who rated this statement as "strongly agree" and "agree" is slightly higher than $71 \%$ of the whole respondents to the survey. According to the Likert scale interpretation, the mean value ranges between 3.4 and less than 4.2, making the level of agreement for this statement high.

\section{Lack of Experts}

Following the data related to the statement of a lack of experts, the choices of "strongly agree" and "agree" for the below statements, ranged from between slightly higher than $72 \%$ and $80.4 \%$ of the whole respondents to the survey. In contrast, both "strongly disagree" and "disagree" ranged between $9.4 \%$ and slightly less than $13 \%$. Besides, the percentages of the "neutral" choice had a relatively high percentage, from $8.4 \%$ for the first statement to $17.8 \%$ of the whole respondents to the survey. Moreover, the results from Table 8 below, relate to the statement of a "Lack of experts", which can be explained based on the average level of respondents' agreement as follows:

Statement 1: "Lack of expertise and specialists in TQM". The percentage of respondents, who rated this statement as

Table 7 Descriptive statistics for lack of delegation authority and responsibility

\begin{tabular}{|c|c|c|c|c|c|c|c|}
\hline Statements & Strongly Agree & Agree & Neutral & Disagree & $\begin{array}{l}\text { Strongly } \\
\text { Disagree }\end{array}$ & Mean & SD \\
\hline $\begin{array}{l}\text { Lack of delegated authority from the top management to other managerial } \\
\text { levels. [B3.1] }\end{array}$ & 26.4 & 38.9 & 13.5 & 11.8 & 9.3 & 3.7 & 0.7 \\
\hline Work responsibilities are not delegated at the company. [B3.2] & 23.7 & 43.2 & 16.1 & 12.7 & 4.2 & 3.6 & 0.9 \\
\hline $\begin{array}{l}\text { Managers at middle and junior levels follow instructions more than creating } \\
\text { proposals in their jobs. [B3.3] }\end{array}$ & 34.7 & 36.4 & 12.7 & 9.4 & 6.7 & 3.8 & 0.7 \\
\hline
\end{tabular}

Table 8 Descriptive statistics for Lack of TQM Experts

\begin{tabular}{|c|c|c|c|c|c|c|c|}
\hline Statements & Strongly Agree & Agree & Neutral & Disagree & $\begin{array}{l}\text { Strongly } \\
\text { Disagree }\end{array}$ & Mean & SD \\
\hline Lack of expertise and specialists in TQM. [B4.1] & 31.3 & 49.1 & 8.4 & 5.9 & 5.2 & 3.9 & 0.7 \\
\hline Shortage of knowledge and skills to implement TQM. [B4.2] & 50.6 & 26.2 & 10.1 & 7.8 & 5.1 & 4.1 & 0.9 \\
\hline There are wrong people in the wrong position. [B4.3] & 23.7 & 48.4 & 17.8 & 5.2 & 4.2 & 3.9 & 0.8 \\
\hline
\end{tabular}


"agree" and "strongly agree" is the highest at $80.4 \%$ of the whole respondents to the survey. According to the Likert scale interpretation, the mean value ranges between 3.4and less than 4.2, so the level of agreement for this statement is high.

Statement 2: "Shortage of knowledge and skills to implement TQM". The percentage of respondents, who rated this statement as "strongly agree" and "agree" is $76.8 \%$ of the whole respondents to the survey. According to the Likert scale interpretation, the mean value ranges between 3.4 and less than 4.2, thus the level of agreement for this statement is high.

Statement 3: "There are wrong people in the wrong position". The percentage of respondents, who rated this statement as "strongly agree" and "agree" is slightly higher than $72 \%$ of the whole respondents to the survey. According to the Likert scale interpretation, the mean value ranges between 3.4 and less than 4.2, indicating that the level of agreement for this statement is high.

\section{Bureaucratic Management}

The data related to the statement of bureaucratic management show that the choices of "strongly agree" and "agree" for the below statements ranged from 55\% to slightly higher than $71 \%$ of the whole respondents to the survey. On the other hand, both "strongly disagree" and "disagree" ranged between $18.7 \%$ and $25.4 \%$ of the whole respondents.

Whereas, the percentages of the "neutral" choice had a relatively high percentage with an average of $13.5 \%$ of the whole respondents to the survey. Also, the results from Table 9 refer to the statement of "Bureaucratic management", and can be explained based on the average level of respondents' agreement as follows:

Statement 1: "The bureaucratic management style is prevalent". The percentage of respondents, who rated this statement as "agree" and "strongly agree" is $55 \%$ of the whole respondents to the survey. According to the Likert scale interpretation, the mean value ranges between 3.4 and less than 4.2, resulting in the level of agreement for this statement being high.

Statement 2: "The management style does not encourage and motivate the staff to be innovative and efficient".
The percentage of respondents, who rated this statement as "agree" and "strongly agree" is slightly higher than $69 \%$ of the whole respondents to the survey. According to the Likert scale interpretation, the mean value ranges between 3.4 and less than 4.2, making the level of agreement for this statement high.

Statement 3: "The Company focuses on the results more than the process". The mean value of the agreement with this statement is $3.6 \%$, with a relatively low standard deviation of $0.7 \%$. The percentage of respondents, who rated this statement as "agree" and "strongly agree" is slightly higher than $71 \%$ of the whole respondents to the survey. According to the Likert scale interpretation, the mean value ranges between 3.4 and less than 4.2, hence the level of agreement for this statement is high.

\section{Poor ineffective training and development}

About poor ineffective training and development, the results demonstrate that the choices of "strongly agree" and "agree" for this statement ranged between 53.3 and $75.4 \%$ of the whole respondents to the survey. While, both the "strongly disagree" and "disagree" choices ranged from between $16.8 \%$ and slightly less than $33 \%$ of the whole respondents to the survey. Moreover, the results clarified that the percentages for the "neutral" choice were $6.7 \%$ for the second statement and $13.5 \%$ for the third statement of the whole respondents to the survey. Also, the results from Table 10 below, relate to the statement of "poor ineffective training", which can be explained based on the average level of respondents' agreement as follows:

Statement 1: "There is a shortage of qualified trainers at the company". With the percentage of respondents, who rated this statement as "agree" and "strongly agree" at 75.4\% of the whole respondents to the survey. According to the Likert scale interpretation, the mean value ranges between 3.4 and less than 4.2 , so the level of agreement for this statement is high.

Statement 2: "There are difficulties in achieving training targets at the company". The percentage of respondents, who rated this statement as "agree" and "strongly agree" is high at $63.5 \%$ of the whole respondents to the survey. According to the Likert scale interpretation, the mean value ranges

Table 9 Descriptive statistics for Bureaucratic Management Style

\begin{tabular}{|c|c|c|c|c|c|c|c|}
\hline Statements & Strongly Agree & Agree & Neutral & Disagree & $\begin{array}{l}\text { Strongly } \\
\text { Disagree }\end{array}$ & Mean & $\mathrm{SD}$ \\
\hline The bureaucratic management style is prevalent. [B5.1] & 11.8 & 43.2 & 19.4 & 16.1 & 9.3 & 3.3 & 0.8 \\
\hline $\begin{array}{l}\text { The management style does not encourage and motive the staff to } \\
\text { be innovative and efficient. [B5.2] }\end{array}$ & 31.9 & 37.2 & 11.1 & 10.3 & 9.4 & 3.7 & 0.8 \\
\hline The company focuses on the results more than the process. [B5.3] & 22.8 & 48.3 & 10.1 & 7.6 & 11.1 & 3.6 & 0.7 \\
\hline
\end{tabular}


Table 10 Descriptive statistics for poor ineffective training and development

\begin{tabular}{|c|c|c|c|c|c|c|c|}
\hline Statements & Strongly Agree & Agree & Neutral & Disagree & $\begin{array}{l}\text { Strongly } \\
\text { Disagree }\end{array}$ & Mean & SD \\
\hline There is a shortage of qualified trainers at the company. [B6.1] & 31.3 & 44.1 & 7.6 & 10.1 & 6.7 & 3.8 & 0.8 \\
\hline There are difficulties in achieving training targets at the company. [B6.2] & 28.8 & 34.7 & 6.7 & 18.6 & 11.1 & 3.5 & 0.9 \\
\hline Lack of modern training methods at the company. [B6.3] & 25.4 & 27.9 & 13.5 & 19.4 & 13.5 & 3.3 & 0.9 \\
\hline
\end{tabular}

between 3.4 and less than 4.2, as a result, the level of agreement for this statement is high.

Statement 3: "Lack of modern training methods at the company". With the percentage of respondents, rating this statement as "agree" and "strongly agree" higher than 53\% of the whole respondents to the survey. Following the Likert scale interpretation, the mean value ranges between 3.4 and less than 4.2, thus the level of agreement for this statement is high.

Above section identified and executed a descriptive analysis of the most significant key factor and barriers that hinder successful TQM implementation. Following that, inferential statistical data analysis has been performed to ascertain the correlation relationship of the most significant key factor of TQM, which is top management commitment, with its related TQM barriers.

\section{Inferential data analysis}

An inferential analysis aims to identify patterns in the data; for example, whether there is a link between two variables, or whether certain groups are more likely to show certain attributes. This analysis aims to draw lessons from a valid sample of this study that can be generalised for the wider population. This section concentrates on a correlation analysis of TQM key factor; TMC discussed in the literature review. The key factor of TMC has been correlated with seven barriers that hinder TQM's successful implementation. The correlation analysis has been conducted through two stages. The first stage clarifies the degree of correlation between the barriers of TQM and the key factor of TQM implementation; top management commitment. The second stage summaries the relationship by listing the related barriers regarding their degree of correlation with TMC as the key factor of TQM.

\section{The correlation of TMC with barriers}

Table 11 below indicates that each sub-factor of TMC has a different level of negative correlation with some TQM barriers. These range from a significant correlation, where the $\rho$-value was less than 0.01 , to a moderately significant correlation where the $\rho$-value was equal to 0.045 . Based on the correlation analysis, sub-factor 1 shows a significant correlation with resistance to change in addition to moderately significant correlation with bureaucratic management. While sub-factor 2 indicates a moderately significant correlation with poor understanding and insufficient knowledge of TQM. At the same time, sub-factor 3 demonstrates a significant correlation with, Lack of delegation of authority and responsibility, bureaucratic management and poor ineffective training and development in addition to a moderately significant correlation with resistance to change.

Based on an analysis of the data contained in Table 11 above, the correlation results illustrate one of the key factors of TQM, which is top management commitment, with its related barriers. These correlated barriers have been listed regarding the degree of correlation from high to low. Table 12 below, will explain this further:

1. Demonstrating its commitment to quality top management continually would contribute to overcoming or reducing the negative impacts of resistance to change and bureaucratic management.

2. Allocating adequate time and resources for quality management means that top management will contribute to overcoming or reducing the negative impacts of poor understanding and insufficient knowledge of TQM.

3. Using performance indicators to ensure adequate performance, top management will contribute to overcoming or reducing the negative impacts of poor ineffective training and development, Lack of delegation of authority and responsibility, bureaucratic management and resistance to change.

\section{Discussion of the findings}

This chapter discusses the key findings from the analysis of data derived from the questionnaire survey which were presented in the previous section. The research findings discussed in this section are structured into two sections; TMC as the most significant key factor for TQM implementation; and the relationship of TQM with the barriers that hinder successful TQM implementation. 
Table 11 Spearman's Correlation for TMC with Barriers of TQM

\begin{tabular}{|c|c|c|c|c|c|}
\hline \multirow[t]{2}{*}{ Barriers of TQM } & & & \multicolumn{3}{|c|}{ Top management commitment } \\
\hline & & & Sub-factor 1 & Sub-factor 2 & Sub-factor 3 \\
\hline \multirow[t]{9}{*}{ Poor understanding and insufficient knowledge of TQM } & \multirow[t]{3}{*}{ B1.1 } & Correlation Coefficient & 0.017 & 0.061 & 0.017 \\
\hline & & Sig. (2-tailed) & 0.859 & 0.515 & 0.856 \\
\hline & & $\mathrm{N}$ & 118 & 118 & 118 \\
\hline & \multirow[t]{3}{*}{ B1.2 } & Correlation Coefficient & -0.125 & $-.209 *$ & -0.110 \\
\hline & & Sig. (2-tailed) & 0.178 & 0.023 & 0.238 \\
\hline & & $\mathrm{N}$ & 118 & 118 & 118 \\
\hline & \multirow[t]{3}{*}{ B1.3 } & Correlation Coefficient & 0.008 & 0.034 & 0.113 \\
\hline & & Sig. (2-tailed) & 0.928 & 0.714 & 0.225 \\
\hline & & $\mathrm{N}$ & 118 & 118 & 118 \\
\hline \multirow[t]{9}{*}{ Resistance to change } & \multirow[t]{3}{*}{ B2.1 } & Correlation Coefficient & -0.071 & -0.096 & 0.092 \\
\hline & & Sig. (2-tailed) & 0.445 & 0.303 & 0.321 \\
\hline & & $\mathrm{N}$ & 118 & 118 & 118 \\
\hline & \multirow[t]{3}{*}{ B2.2 } & Correlation Coefficient & $-.294 * *$ & 0.082 & $-.225^{*}$ \\
\hline & & Sig. (2-tailed) & 0.001 & 0.383 & 0.016 \\
\hline & & $\mathrm{N}$ & 118 & 118 & 118 \\
\hline & \multirow[t]{3}{*}{ B2.3 } & Correlation Coefficient & 0.147 & 0.084 & 0.167 \\
\hline & & Sig. (2-tailed) & 0.112 & 0.367 & 0.071 \\
\hline & & $\mathrm{N}$ & 118 & 118 & 118 \\
\hline \multirow[t]{9}{*}{ Lack of delegation of authority and responsibility } & \multirow[t]{3}{*}{ B3.1 } & Correlation Coefficient & -0.086 & -0.113 & $-.267 * *$ \\
\hline & & Sig. (2-tailed) & 0.356 & 0.224 & 0.003 \\
\hline & & $\mathrm{N}$ & 118 & 118 & 118 \\
\hline & \multirow[t]{3}{*}{ B3.2 } & Correlation Coefficient & 0.022 & 0.027 & 0.135 \\
\hline & & Sig. (2-tailed) & 0.813 & 0.771 & 0.144 \\
\hline & & $\mathrm{N}$ & 118 & 118 & 118 \\
\hline & \multirow[t]{3}{*}{ B3.3 } & Correlation Coefficient & 0.124 & 0.156 & 0.126 \\
\hline & & Sig. (2-tailed) & 0.181 & 0.092 & 0.173 \\
\hline & & $\mathrm{N}$ & 118 & 118 & 118 \\
\hline \multirow[t]{9}{*}{ Lack of TQM experts } & \multirow[t]{3}{*}{ B4.1 } & Correlation Coefficient & -0.060 & -0.104 & -0.062 \\
\hline & & Sig. (2-tailed) & 0.518 & 0.263 & 0.502 \\
\hline & & $\mathrm{N}$ & 118 & 118 & 118 \\
\hline & \multirow[t]{3}{*}{ B 4.2} & Correlation Coefficient & -0.095 & -0.120 & -0.040 \\
\hline & & Sig. (2-tailed) & 0.304 & 0.196 & 0.667 \\
\hline & & $\mathrm{N}$ & 118 & 118 & 118 \\
\hline & \multirow[t]{3}{*}{ B4.3 } & Correlation Coefficient & 0.028 & -0.142 & 0.030 \\
\hline & & Sig. (2-tailed) & 0.761 & 0.125 & 0.748 \\
\hline & & $\mathrm{N}$ & 118 & 118 & 118 \\
\hline \multirow[t]{9}{*}{ Bureaucratic management } & \multirow[t]{3}{*}{ B5.1 } & Correlation Coefficient & 0.092 & 0.045 & -0.020 \\
\hline & & Sig. (2-tailed) & 0.324 & 0.625 & 0.833 \\
\hline & & $\mathrm{N}$ & 118 & 118 & 118 \\
\hline & \multirow[t]{3}{*}{ B5.2 } & Correlation Coefficient & $-.232 *$ & 0.032 & 0.056 \\
\hline & & Sig. (2-tailed) & 0.012 & 0.732 & 0.549 \\
\hline & & $\mathrm{N}$ & 118 & 118 & 118 \\
\hline & \multirow[t]{3}{*}{ B5.3 } & Correlation Coefficient & 0.079 & -0.018 & $-.262 * *$ \\
\hline & & Sig. (2-tailed) & 0.426 & 0.865 & 0.004 \\
\hline & & $\mathrm{N}$ & 118 & 118 & 118 \\
\hline
\end{tabular}


Table 11 (continued)

\begin{tabular}{|c|c|c|c|c|c|c|c|}
\hline & \multicolumn{3}{|c|}{ Top management commitment } \\
\hline \multicolumn{5}{|c|}{ Barriers of TQM } & \multirow{2}{*}{$\begin{array}{l}\text { Sub-factor } 1 \\
0.020\end{array}$} & \multirow{2}{*}{$\begin{array}{l}\text { Sub-factor } 2 \\
0.046\end{array}$} & \multirow{2}{*}{$\frac{\text { Sub-factor } 3}{-0.056}$} \\
\hline \multirow{9}{*}{\multicolumn{2}{|c|}{ Poor ineffective training and development }} & B6.1 & \multirow{2}{*}{\multicolumn{2}{|c|}{$\begin{array}{l}\text { Correlation Coefficient } \\
\text { Sig. (2-tailed) }\end{array}$}} & & & \\
\hline & & & & & 0.832 & 0.617 & 0.545 \\
\hline & & & \multicolumn{2}{|l|}{$\mathrm{N}$} & 118 & 118 & 118 \\
\hline & & B6.2 & \multicolumn{2}{|c|}{ Correlation Coefficient } & 0.079 & 0.124 & $-.296^{* *}$ \\
\hline & & & \multicolumn{2}{|c|}{ Sig. (2-tailed) } & 0.393 & 0.182 & 0.001 \\
\hline & & & \multicolumn{2}{|l|}{$\mathrm{N}$} & 118 & 118 & 118 \\
\hline & & B6.3 & \multicolumn{2}{|c|}{ Correlation Coefficient } & -0.147 & -0.052 & 0.152 \\
\hline & & & \multicolumn{2}{|c|}{ Sig. (2-tailed) } & 0.113 & 0.579 & 0.101 \\
\hline & & & \multicolumn{2}{|l|}{$\mathrm{N}$} & 118 & 118 & 118 \\
\hline \multicolumn{8}{|c|}{$\begin{array}{l}{ }^{* *} \text { Correlation is significant at the } 0.01 \text { level (2-tailed) } \\
{ }^{*} \text { Correlation is significant at the } 0.05 \text { level (2-tailed) }\end{array}$} \\
\hline \multicolumn{8}{|c|}{ Table 12 Summarising Correlation Results for TMC with Barriers of TQM } \\
\hline \multicolumn{4}{|c|}{ No Top Management Commitment } & \multicolumn{4}{|c|}{ Related TQM barriers from high correlation to low correlation } \\
\hline \multirow[t]{2}{*}{1} & \multirow{2}{*}{\multicolumn{3}{|c|}{ Top management continually demonstrates its commitment to quality }} & \multicolumn{4}{|c|}{ Resistance to change } \\
\hline & & & & \multicolumn{4}{|c|}{ Bureaucratic management } \\
\hline \multirow[t]{5}{*}{2} & $\begin{array}{l}\text { Top management is inclined to allocat } \\
\text { quality management }\end{array}$ & and reso & rces for & \multicolumn{4}{|c|}{ Poor understanding and insufficient knowledge of TQM } \\
\hline & \multirow{4}{*}{$\begin{array}{l}\text { Top management uses performance in } \\
\text { mance }\end{array}$} & re adequ & e perfor- & \multirow{2}{*}{\multicolumn{4}{|c|}{$\begin{array}{l}\text { Poor ineffective training and development } \\
\text { Lack of delegation of authority and responsibility }\end{array}$}} \\
\hline & & & & & & & \\
\hline & & & & \multicolumn{4}{|c|}{ Bureaucratic management } \\
\hline & & & & \multicolumn{4}{|c|}{ Resistance to change } \\
\hline
\end{tabular}

\section{Top management commitment (TMC)}

The success of all quality initiatives such as TQM starts from the TMC. Moreover, the primary findings from the analysis of questionnaire data, as illustrated in Sect. 4.1.1.1, indicated that most of the respondents' answers were between 75 and $84.7 \%$. This showed their agreement with each statement related to the TMC as the starting point and the solid foundation required for successful TQM implementation. Additionally, the mean value of these statements was between 3.9 and 4.1. Thus, based on the Likert scale interpretation (see Table 2), the level of respondents' agreement with these statements was high. These findings are similar to that found in the literature review such as a study conducted in Egyptian manufacturing companies by Salaheldin (2003) who confirmed that TMC was the essential key factor that stimulated TQM implementation, (using the five-point Likert scale). Therefore, based on the above-mentioned discussion, it can be stated that TMC is the essential driving force required for TQM implementation in the company.

\section{Correlation of TMC with barriers}

Companies which aim at implementing TQM ought to have a profound understanding of the barriers, factors required for successful implementation and the relationship between them before initiating the process of application and implementation of TQM. One of the most palpable ways in which some of TQM barriers and the key factors for the implementation of TQM are related is that a majority of them involve human resources or factors (Catalin et al. 2014). For instance, TMC and leadership as the most significant key factor involves human factors which act as the driving forces and decide on the direction which these particular factors should take-whether positive or negative (Case and Srikantia 1998; Kasongo and Moono 2010). In simpler terms, it is the human forces that act as the main drivers in these particular factors. Additionally, both the barriers that are responsible for hindering the implementation of TQM implementation as well as the most vital factors that are necessary for the implementation of TQM relate in a manner in which nearly all-if not all-centrally touch 
on the employees. Therefore, understanding the relationship between the barriers that hinder TQM and the key factors required for TQM implementation will support the oil company to invest in the most effective TQM key factor required to overcome or to reduce the high level of the negative impacts of the barriers that hinder the successful TQM implementation.

The primary findings of the inferential statistics in Sect. 4.2 presented the TMC key factor alongside its inverse correlations with the seven TQM barriers. It has been found that each barrier required the oil company to improve and enhance TMC to improve its opportunities regarding overcoming or reducing the negative impact of these barriers that impeded successful TQM implementation. As the most significant key factor, TMC has a different level of negative correlation with particular barriers that can greatly affect the company's ability to overcome or reduce the negative impact of the barriers in certain areas. This is attributed to the inverse correlation between TMC and each specific TQM barriers. The key factor, TCM can be considered a baseline for any plan aiming to overcome the correlated TQM barriers. This means that improving and enhancing TCM required to overcome the TQM barriers can be considered as the essential step in successful TQM implementation process.

Among the identified barriers, only the 'lack of TQM experts' had not any frequency with the TMC factor. Moreover, if the Oil Company has a limited budget, time and qualified human resource for overcoming all these barriers it can use a correlation ranking to decide which barrier need to be overcome first. Meanwhile, the extent to which overcoming the barriers is achieved will be determined by the effective TMC. For instance, if TMC shows a significant correlation with particular barriers, this means that TMC need to be developed and enhanced in order to overcome or reduce the negative impact of those barriers.

\section{Conclusions}

The main findings of the study obtained from literature and case study investigation revealed that TQM has been widely researched and adopted in industrialised nations but in the context of Iraq no single study exists which adequately covers the TQM implementation in general and in the Iraqi oil industry in particular. Accordingly, this study has addressed a knowledge gap on the level of TQM implementation in one of the most significant and unique oil companies in the Iraqi oil industry which is the Iraqi Drilling Company (IDC). This study was aimed to identify the key factors of TQM implementation, barriers that hinder TQM implementation and to investigate their relationship. Thus, from the research findings, it has been found that the top management commitment has a vast contribution towards the successful TQM implementation and it has an inverse correlation between each of specific TQM barrier. This explains that each barrier required the oil company to improve and enhance its TMC to improve its opportunities regarding overcoming or reducing the negative impact of these barriers that impeded successful TQM implementation.

Funding No particular funding for this study.

\section{Declarations}

Conflicts of interest On behalf of all the co-authors, the corresponding author states that there is no conflict of interest.

Open Access This article is licensed under a Creative Commons Attribution 4.0 International License, which permits use, sharing, adaptation, distribution and reproduction in any medium or format, as long as you give appropriate credit to the original author(s) and the source, provide a link to the Creative Commons licence, and indicate if changes were made. The images or other third party material in this article are included in the article's Creative Commons licence, unless indicated otherwise in a credit line to the material. If material is not included in the article's Creative Commons licence and your intended use is not permitted by statutory regulation or exceeds the permitted use, you will need to obtain permission directly from the copyright holder. To view a copy of this licence, visit http://creativecommons.org/licenses/by/4.0/.

\section{References}

Abd-Elwahed M, El-Baz M (2018) Impact of implementation of total quality management: an assessment of the Saudi Industry. S Afr J Ind Eng 29(1):97-107. https://doi.org/10.7166/29-1-1902

Addis S (2019) An exploration of quality management practices in the manufacturing industry of Ethiopia. TQM J 32(1):127-142

Ahmad M, Elhuni R (2014) Critical Quality Factors for successful TQM implementation in Libyan Oil and Gas sector. Benchmark An Int J 21(5):733-713

Ahmed T, Lodhi M (2015) Effectiveness of TQM philosophy at operational level for quality product in Pakistan: empirical study of textile dyeing Industry. J Bus Manag 17(4):45-59

Al-Khalifa KN, Aspinwall EM (2000) The development of total quality management in Qatar. TQM Magazine 12(3):194-204

Al-Shammari R. (2013). Quality management (QM) implementation in the Kuwaiti Oil Industry: An empirical study and a proposed generic framework. PhD thesis, Aston University.

Alsughayir A (2014) Does practicing total quality management affect employee job satisfaction in Saudi Arabian organizations? Eur J Business Manage 6(3):169-175

American Society for Quality (ASQ). (2015). Total Quality Management (TQM). http://asq.org/learn-about-quality/total-qualitymanagement/overview/overview.html

Beckford J (2010) Quality: a critical introduction, 3rd edn. Routledge, New York

Benghida S (2017) Factors and challenges in developing countries under the Resource Curse. Int J Civil Eng Technol 8(11):901-910

Berrouiguet A (2013) Barriers to implementing total quality management in Algerian manufacturing organizations. Valahian J Econ Stud 4(18):61-66 
Besterfield D, Besterfield-Michna C, Besterfield GH, Besterfield-Sacre M, Urdhwareshe H, Urdhwarshe R (2012) Total quality management, 3rd edn. New Delhi, Dorling Kindersley

Bishop P, Herron R (2015) Use and misuse of the likert item responses and other ordinal measures. Int J Exerc Sci 8(3):297-302

Bouranta N, Psomas E, Suárez-Barraza M, Jaca C (2019) The key factors of total quality management in the service sector: a crosscultural study. Benchmarking 26(3):893-921

Case SS, Srikantia P (1998) Factors influencing TQM implementation in knowledge work environments: an integrative framework. In Academy of Management Annual Meeting, San Diego

Castagna F, Centobelli P, Cerchione R, Esposito E, Oropallo E, Passaro R (2020) Customer knowledge management in SMEs facing digital transformation. Sustainability 12(9):3899. https://doi.org/ $10.3390 /$ su 12093899

Cătălin SH, Bogdan B, Dimitrie GR (2014) The existing barriers in implementing total quality management. Analele Universitatii din Oradea Stiinte Economice 1:1234-1240

Crosby PB (1979) Quality is free: the art of making quality certain. McGraw-Hill, New York

Dale BG, Wiele TVD, Iwaarden JV (2013) Managing quality, 5th edn. Blackwell Publishing Ltd, Oxford

Dedy A, Zakuan N, Zaidi Bahari A, Ariff MSM, Chin TA, Saman ZM, M. (2016) Identifying critical success factors for TQM and employee performance in Malaysian automotive industry: a literature review. Mater Sci Eng Conf Ser 131(1):7

EFQM (2010). Introduction to EFQM model. http://www.efqm.org.

Escanciano C, Fernández E, Vázquez C (2001) Influence of ISO 9000 certification on the progress of Spanish industry towards TQM. Int J Qual Reliabil Manage 18(5):481-494

Flynn BB, Schroeder RG, Sakakibara S (1994) A framework for quality management research and an associated measurement instrument. J Operat Manage 11(4):339-366

García-Alcaraz J, Montalvo F, Sánchez-Ramírez C, Avelar-Sosa L, Saucedo J, Alor-Hernández G (2019) Importance of organizational structure for TQM success and customer satisfaction. Wireless Netw. https://doi.org/10.1007/s11276-019-02158-5

Gherbal N, Shibani A, Saidani M, Sagoo A (2012) Critical success factors of implementing total quality management in Libyan Organizations. In International Conference on Industrial Engineering and Operations Management Istanbul, Turkey (pp. 80-89).

Górny A (2017) Total quality management in the improvement of work environment-conditions of ergonomics. Advances in Intelligent Systems and Computing. Springer, Cham, pp 91-100

Hietschold N, Reinhardt R, Gurtner S (2014) Measuring critical success factors of TQM implementation successfully-a systematic literature review. Int J Prod Res 52(21):6254-6272

Hoe L, Mansori S (2018) The effects of product quality on customer satisfaction and loyalty: evidence from Malaysian Engineering Industry. Int J Ind Market 3(1):20

Ismail L (2012) An evaluation of the implementation of Total Quality Management (TQM) within the construction sector in the United Kingdom and Jordan. Doctoral thesis, University of Huddersfield.

Jacobsen J (2008) Avoiding mistakes of the past: lessons learned on what makes or breaks quality initiatives. J Qual Participat 31(2):4-9

Jones J, Seraphim D (2008) TQM implementation and change management in an unfavourable environment. J Manage Dev 27(3):291-306

Jong C, Sim A, Lew T (2019) The relationship between TQM and project performance: empirical evidence from Malaysian construction industry. Cogent Business Manag 6(1):1-31

Kanji GK (2012) Total quality management proceedings of the first world congress. Springer: Berlin
Kasongo C, \& Moono M (2010). Factors that lead to a successful TQM implementation: a Case Study on the Zambian Tourism Industry.

Koh TY, Low SP (2010) Empiricist framework for TQM implementation in construction companies. J Manage Eng 26(3):133-143

Kumar R, Garg D, Garg TK (2011) TQM success factors in North Indian manufacturing and service industries. TQM J 23(1):36-46

Lewis WG, Pun KF, Lalla TRM (2006) Exploring soft versus hard factors for TQM implementation in small and medium-sized enterprises. Int J Product Perform Manag 55(7):539-554

Madsen D (2020) Have the reports of TQM's death been greatly exaggerated? A re-examination of the concept's historical popularity trajectory. Admin Sci 10(2):32

McLeod A, Pippin S, Wong J (2011) Revisiting the Likert scale: can the fast form approach improve survey research. Int J Behav Account Finan 2(3/4):310

Neyestani B, Juanzon JBP (2016) Identification of A set of appropriate critical success factors for successful TQM implementation in construction, and other industries. Int J Adv Res 4(11):1581-1591

Nyutu EN, Cobern WW, Pleasants BA-S (2021) Correlational study of student perceptions of their undergraduate laboratory environment with respect to gender and major. Int J Educ Math Sci Technol 9(1):83-102

Pambreni Y, Khatibi A, Azam S, Tham J (2019) The influence of total quality management toward organization performance. Management Sci Lett 9:1397-1406

Richard J (2012) Total quality management. Business Manage Strategy $3(2): 36-42$

Salaheldin S (2003) The implementation of TQM strategy in Egypt: a field-force analysis. TQM Magazine 15(4):266-274

Saunders M, Lewis P, Thornhill A (2019) Research methods for business students, 8th edn. Pearson, Harlow

Sekaran U, Bougie R (2010) Research methods for business: a skillbuilding approach. Wiley, New York

Siregar I, Nasution A, Sari R (2017) Effect of total quality management on the quality and productivity of human resources. IOP Conference Series: Materials Science and Engineering, p 180.

Skrabec QR (1999) Quality assurance revisited. Industrial Management 41(6):6-9

Sun H (2000) Total quality management, ISO9000 certification and performance improvement. Int J Qual Reliabil Manage 17(2): 168-179

Sweis R, Ismaeil A, Obeidat B, Kanaan R (2019) Reviewing the literature on total quality management and organizational performance. J Business Manage 7(3):192-215

Twaissi NM, Rollins R, Worsdale G (2008) A review of current issues and challenges for TQM implementations in the Jordanian information and communications technology sector. Middle East Quality Association e-TQM College.

Watson P, Howarth T (2012) Construction quality management: principles and practice. Routledge.

Yin R, K. (2014) Case study research: design and methods, 5th edn. Sage, Los Angeles

Żelechowska D, Żyluk N, Urbański M (2020) Find out a new method to study abductive reasoning in empirical research. Int J Qualit Methods 19:160940692090967

Publisher's Note Springer Nature remains neutral with regard to jurisdictional claims in published maps and institutional affiliations. 